\title{
PENURUNAN KADAR BOD DAN COD AIR LIMBAH UPT PUSKESMAS JANTI KOTA MALANG DENGAN METODE CONTRUCTED WETLAND
}

\author{
Oleh : Endro Sasono *) dan Pungut ${ }^{* *}$ )
}

\begin{abstract}
Abstrak
Penelitian ini dilakukan untuk mengetahui perbedaan dan efisiensi tanaman air, yaitu melati air ( Echinodorus palaefolius) dan bambu air ( Equisetum hymale) dalam menurunkan kandungan BOD dan COD pada air limbah puskesmas. Untuk mengetahui kemampuan tanaman air dalam mendegradasi polutan digunakan sistem sunsurface contructed wetland yang terdiri atas 2 ( dua ) reaktor. Reaktor I berisi media tanam dan tanaman air yaitu melati air ( Echinodorus palaefolius ), reaktor II berisi media tanam dan tanaman air yaitu bambu air ( Equisetum hymale ). Air limbah puskesmas yang akan diuji dialirkan secara tidak kontinyu. Sampel air limbah diambil dari outlet masing-masing reaktor setiap 2 (dua) hari sebanyak 3 (tiga) kali dan dianalisa kandungan BOD dan COD nya.

Hasil penelitian menunjukkan melati air lebih efektif dalam menurunkan kadar BOD dan COD pada air limbah puskesmas. Tanaman melati air memiliki efisiensi penurunan kadar BOD rata-rata $92 \%$ dan COD rata-rata $92 \%$. Tanaman bambu air memiliki efisiensi penurunan kadar BOD rata-rata $86 \%$ dan COD rata-rata $84 \%$. Kesimpulannya bahwa melati air lebih efisien dalam menurunkan kadar BOD dan COD dibanding bambu air.
\end{abstract}

Kata Kunci : Air Limbah, Penurunan BOD dan COD, Melati Air, Bambu Air

\section{PENDAHULUAN}

Air merupakan sumber daya alam yang mempunyai peranan penting bagi kehidupan manusia, sehingga perlu dilindungi agar tetap bermanfaat bagi kehidupan manusia dan makhluk hidup lainnya. Semakin meningkatnya jumlah penduduk dengan segala aktifitasnya, maka keberadaan air dewasa ini sudah banyak mengalami pencemaran, baik dari limbah rumah tangga, industri. Sumber pencemar lain dapat juga berasal dari perkantoran, rumah makan, lembaga termasuk puskesmas dan rumah sakit. Berdasarkan PP Nomer 20 Tahun 1990 tentang Pengendalian Pencemaran Air, pencemaran air adalah turunnya kualitas air sampai ke tingkat tertentu yang menyebabkan air tidak dapat berfungsi lagi sesuai peruntukannnya.

Puskesmas sebagai layanan publik adalah tempat memberikan pelayanan kesehatan dasar strata pertama kepada masyarakat secara langsung, meliputi kegiatan : pelayanan rawat jalan, rawat inap, persalinan serta penunjang seperti laboratorium. Sebagai dampak negatif dari pelayanan publik tersebut, menghasilkan air limbah yang berpotensi menimbulkan pencemaran.

Karakteristik air limbah puskesmas secara keseluruhan hampir sama dengan air limbah rumah sakit, yang meliputi : limbah domestik, yakni buangan kamar mandi, dapur; limbah cair klinis yakni air limbah dari kegiatan klinis, misalnya air bekas cuci luka, cucian darah dan lainlain; air limbah laboratorium. Dampak negatif pembuangan air limbah secara langsung ke badan air atau saluran terbuka dapat menyebabkan terjadinya penurunan kualitas air.

Puskesmas Janti adalah salah satu puskesmas di kota Malang yang selama ini membuang air limbahnya langsung ke saluran air umum.

Air limbah yang berasal dari limbah puskesmas merupakan salah satu sumber pencemaran air yang sangat potensial.

Hal ini disebabkan karena air limbah puskesmas mengandung senyawa organik yang sangat tinggi, juga kemungkinan mengandung senyawa kimia lain serta mikroorganisme pathogen yang dapat menyebabkan penyakit terhadap masyarakat di sekitarnya. Hal ini dapat diketahui dengan hasil analisa kandungan BOD dan COD yang tinggi diatas baku mutu yang diperkenankan yaitu $381,9 \mathrm{mg} / \mathrm{L}$ dan $1360 \mathrm{mg} / \mathrm{L}$,

\footnotetext{
*) Mahasiswa Teknik Lingkungan

**)Dosen Teknik Lingkungan

Universitas PGRI Adi Buana Surabaya
}

60 Jurnal Teknik WAKTU Volume 11 Nomor 01 - Januari 2013 - ISSN : 1412-1867 
sedangkan menurut penelitian sebelumnya tanaman melati air ( Echinodorus palaeforus ) hanya dapat menurunkan konsentrasi nitrat sebesar $55 \%$ dengan teknologi Contructed Wetland ( Riswahyudi, 2010 )

Potensi dampak yang besar tersebut maka setiap puskesmas diharuskan mengolah air limbahnya sampai memenuhi persyaratan standar yang berlaku. Untuk dapat mengatasi pencemaran air limbah yang semakin meningkat maka diperlukan suatu pengolahan air limbah tepat guna.

Salah satu upaya pengolahan air limbah yang cukup efektif dan potensial yaitu dengan metode Contructed Wetland. Contructed Wetland merupakan sebuah teknik pengolahan yang bertujuan untuk meningkatkan kualitas air serta mengurangi polutan dalam air. Contructed Wetland adalah system pengolahan terencana/terkontrol yang di desain dan dibangun dengan menggunakan proses alami, yang melibatkan vegetasi wetland tanah berpasir dan mikroorganisme untuk mengolah air limbah.

Tujuan yang ingin dicapai dalam penelitian ini adalah :

1. Mengetahui karakteristik limbah cair di UPT Puskesmas Janti.

2. Mengetahui perbedaan hasil degradasi limbah cair ditinjau dari jenis tanaman air yaitu Melati air dan Bambu air yang digunakan dalam menurunkan kadar BOD dan COD pada air limbah UPT Puskesmas Janti Kota Malang.

3. Mengetahui efisiensi Contructed Wetland dalam menurunkan kadar BOD dan COD pada pengolahan air limbah UPT Puskesmas Janti.

\section{KAJIAN PUSTAKA \\ Air Limbah Puskesmas}

Air limbah puskesmas

karakteristiknya hampir sama dengan air limbah rumah sakit adalah limbah kompleks dan mempunyai potensi bahaya serius baik jangka pendek maupun jangka panjang, Ahmadi, (1995). Menurut Keputusan Gubernur Jawa Timur Nomor 61 Tahun 1999, bahwa limbah cair adalah limbah dalam wujud cair yang dihasilkan oleh semua kegiatan rumah sakit yang di buang ke lingkungan, dan diduga dapat menurunkan kualitas lingkungan. Pada umumnya karakteristik air limbah puskesmas mengandung berbagai parameter, antara lain : Biologycal Oxygen Demand (BOD), Chemical Oxygen Demand (COD), Total Suspended Solids (TSS), Nitrogen (N), Phosphor dan Detergent.

Air limbah rumah sakit adalah limbah seluruh buangan cair yang berasal dari hasil proses seluruh kegiatan rumah sakit yang meliputi : limbah domestik yakni buangan kamar mandi, dapur, air bekas cucian pakaian; limbah cair klinis yakni air limbah dari kegiatan klinis misalnya air bekas cuci luka, cucian darah, dan lainlain; air limbah laboratorium; kamar bersalin dan lainnya ( Said, 2006 ).

\section{Contructed Wetland}

Contructed Wetland atau Wetland menurut Metcalf dan Eddy ( 2003 ), adalah suatu lahan yang jenuh air dengan kedalaman air tipikal yang kurang dari 0,6 meter yang mendukung pertumbuhan tanaman air emergent, misalnya Cattail, Bulrush, Reeds dan Sedges (Carex,sp ). Sedangkan menurut Hammer ( 1989 ) Wetland adalah pengolahan limbah secara alami yang terdiri dari 3 faktor utama, yaitu :

1.Area yang digenangi air dan mendukung hidupnya aquatic plant jenis hydrophita 2.media tumbuh berupa tanah berpasir yang selalu digenangi air.

3.media jenuh air.

A.Proses - proses Pengolahan Air limbah Sistem Contructed Wetland

Proses pengolahan air limbah pada sistem wetland berlangsung melalui proses fisika, kimia dan biologi yang disebabkan oleh adanya interaksi mikroorganisme, tanaman dan subtract, Mukhlis,( 2003 ).

Prinsip dasar sistem wetland untuk pengolahan air limbah adalah pada proses respirasi tumbuhan air. Tumbuhan air ini mampu menghisap oksigen dari udara melalui daun, batang, akar dan rhizomanya yang kemudian dilepaskan kembali pada daerah sekitar perakaran ( rhizosphere ).Hal ini dimungkinkan karena jenis tumbuhan air ini mempunyai ruang antar sel atau lubang saluran udara sebagai alat transportasi oksigen dari atmosfer ke bagian perakaran.

Tipe-tipe Wetland 
Menurut Novotny dan Olem, 1984, wetland dapat dibedakan menjadi 2 tipe, yaitu :

1. Wetland dengan aliran di atas permukaan tanah (Free Water Surface )

Wetland dengan sistem Free Water Surface ( FWS ) terdiri dari kolam atau saluran dengan media alami ( tanah ) atau buatan ( pasir/kerikil ) untuk menyokong pertumbuhan tanaman air. Tanaman air mencuat ( emergent aquatic plant ) tumbuh diatas media tanam dan air tercemar diolah pada saat air mengalir diatas permukaan media melalui rumpun tanaman (Meutia, 2001).

2. Wetland dengan aliran di bawah permukaan tanah ( Sub-surface Flow Contructed Wetland )

Wetland dengan system Sub-surface Flow System (SSF ) ini terdiri dari saluran atau kolam dangkal yang berisi tanah, pasir, atau media batu/kerikil yang akan membantu proses penyaringan air. Air tercemar atau air limbah mengalir di bawah permukaan media horizontal melalui zona perakaran tanaman rawa di antara kerikil/pasir (Meutia, 2001).

B. Mekanisme penyisihan bahan pencemar dalam Contructed Wetland

Menurut Campbell \& Ogden, 1999 dalam Kurniawan, 2005 pada dasarnya kandungan organic tidak hilang dalam sistem wetlands ini, melainkan mengalami peristiwa sebagai berikut : (1) Dikonversikan ke plants material; (2) Dikembalikan ke atmosfer; Terendapkan ke dasar wetlands; (4) Dikeluarkan ke aliran air downstream. Sebagai contoh removel fisik dari COD dipercaya terjadi melalui proses pengendapan dan penangkapan material di ruang hampa pada media batuan. Kira-kira sebesar $80 \%$ total COD dihilangkan melalui pengendapan pertama dan 60\%-65\% COD yang dihilangkan tersebut dalam bentuk solid ( Benefield \& Randall, 1980 dalam Kurniawan, 2005 ). Proses penurunan kandungan $\mathrm{COD}$ dalam sistem wetland akan semakin baik bila digunakan media dengan ukuran partikel yang lebih kecil ( Schuls, 2000 dalam Fitriani, 2002).

$$
\text { Begitu juga dengan }
$$

senyawa organic lainnya, dapat dipecah untuk dikonsumsi bagi mikroorganisme dalam sistem wetland. Biodegradasi ini menghilangkan senyawa organic dari air seperti menyediakan energi untuk mikroorganisme ( Lorion, 2001 dalam Fitriani, 2002 ). Tingkat kemampuan biodegradasi dari berbagai macam substansi organic tergantung dari kemampuan degradasi relative dari material, temperature, konsentrasi oksigen, $\mathrm{pH}$, pengadaan nutrient, konsentrasi substrat dan adanya senyawa toksin yang potensial ( Cooper, 1990 dalam Fitriani, 2002 ).

C. Jenis Tanaman yang Digunakan

\section{Melati air ( Echinodorus palaefolius )}

Melati air merupakan tanaman hias yang dapat hidup dalam berbagai musim dan selalu membutuhkan air pada media tanamnya.Melati air dalam pemanfaatannya sebagai pereduktor / filter kontaminan sangat efektif dalam memperluas area tempat mikroorganisme melengket dan akarnya mengeluarkan oksigen sehingga akan membentuk zona rizosfer yang kaya oksigen.

Dari hasil penelitian sebelumnya , diketahui bahwa tanaman Melati air sangat efektif dalam menurunkan kadar zat pencemar.

2. Bambu Air ( Equisetum hyemale )

Bambu air dapat hidup pada vegetasi wetland dengan kecukupan air untuk pertumbuhannya dan hidup dalam berbagai musim. Jenis tanaman bambu air sangat efektif untuk digunakan sebagai media pada wetland karena dari hasil penelitian menunjukkan bahwa bambu air dapat menurunkan kadar BOD sampai ambang batas nilai yang diinginkan.

\section{METODOLOGI}

\section{Desain Reaktor Sub-surface Contructed Wetland}

Pada penelitian ini digunakan 2 buah reaktor kedap air yang dibuat dengan cara membuat galian yg dilapisi terpal plastik kedap air, berbentuk persegi panjang dengan ukuran sesuai dengan debit air limbah yang akan diolah dengan perbandingan ukuran minimal adalah Panjang : Lebar = 3:1 (Wood, 2003 dalam Kurniawan, 2005 ) 
Ukuran dimensi reaktor uji adalah melalui perhitungan sbb :

Debit air limbah yg diolah $\quad: 825$ liter /hari

Waktu tinggal direncanakan : 2 hari Porositas media $\quad: 55 \%$
Volume air limbah diolah

: 825 liter

Maka volume reaktor

: $100 / 55 x$

825 liter $=1,5 \mathrm{M} 3$

Dimensi reaktor

$: \mathrm{P} \times \mathrm{L} \times \mathrm{T}$

$\mathrm{m} \times 0,5 \mathrm{~m}=1,5 \mathrm{M} 3$

Slope (kemiringan )

$$
\text { : } 4 \mathrm{~m} \times 0,75
$$

$: 2 \%$

Hasil perhitungan reaktor uji dituangkan dan dapat dilihat pada gambar 1 ,sebagai berikut :

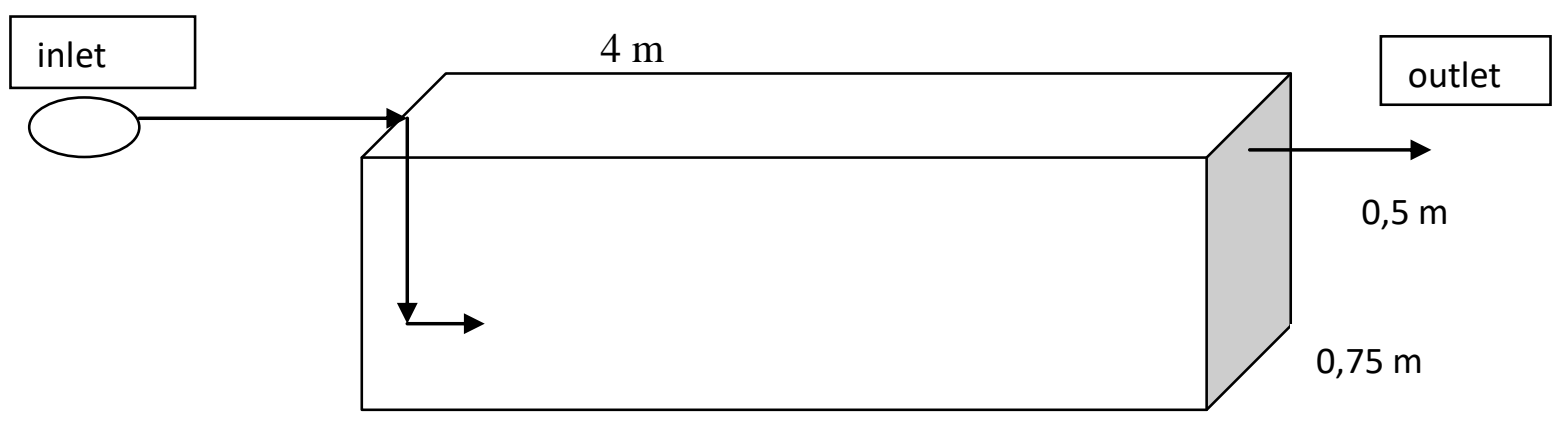

Reaktor yang digunakan sebanyak 2 buah dengan rincian 1 buah reactor berisi media pecahan batu kali dan tanaman melati air, reactor yang lain berisi media pecahan batu kali dan tanaman bambu air. Media tanam yaitu pecahan batu akli ukuran 1-2 cm, media ini dipilih karena memiliki porositas kecil, mudah diperoleh dan harganya murah.

1. Menentukan debit air limbah yang akan diolah karena berkaitan dengan dimensi reactor. Peneliti menggunakan perhitungan debit air limbah adalah $90 \%$ dari debit air bersih, dengan hasil perhitungan tiap reaktor mengolah debit air limbah sebanyak 825 liter/hari.

2. Uji porositas media dilakukan untuk mengetahui porositas media pecahan batu kali yang akan digunakan. Hasil uji porositas media batu kali ukuran 1-2 cm adalah 55 $\%$.

3. Menentukan waktu tinggal $(t)$ air limbah, karena lamanya waktu tinggal akan berpengaruh terhadap efisiensi penyisihan kandungan air limbah. Waktu tinggal yang dipilih adalah 2 hari.

4. Analisis sampel air limbah Puskesmas Janti untuk mengetahui karakteristiknya.

5. Aklimatisasi tanaman air dilakukan denga tujuan agar tanaman dapat
Sampel air limbah yang diolah berasal dari inlet IPAL Puskesmas Janti dengan rentang kandungan $B O D$ influen antara $39 \mathrm{mg} / \mathrm{l}$ - $71 \mathrm{mg} / \mathrm{l}$ dan rentang kandungan COD influen antara $79 \mathrm{mg} / \mathrm{l} \mathrm{-}$ $161 \mathrm{mg} / \mathrm{l}$.

Tahapan Penelitian menyesuaikan diri dengan media tumbuhnya yang baru. Aklimatisasi dilakukan selama 1 bulan dengan harapan tanaman air sudah dapat menyesuaikan dengan medianya yang baru. aklimatisasi dilakukan dengan menyiramkan air bersih selama 2 minggu, selanjutnya diganti dengan air limbah dari inlet IPAL puskesmas secara bertahap sampai pelaksanaan pengambilan sampel.

6. Pengambilan sampel air limbah di mulai pada awal reactor dinyatakan siap untuk di operasikan ( hari ke nol ) selanjutnya diambil 3 kali dengan interval 2 hari. Sampel diambil pagi hari antara jam 10.00 WIB sampai jam 11.00 WIB.

7. Pengukuran kandungan $B O D$ dan COD influen dan effluent untuk mengetahui efisiensi penurunan kandungan $\mathrm{BOD}$ dan $\mathrm{COD}$ dari 
reactor yang berisi media tanam dan tanaman melati air dan bambu air.

Teknik Pengumpulan Data

1. Effluent yang keluar dari outlet reactor ditampung dalam botol plastic untuk selanjutnya dikirim ke laboratorium Jasa Tirta 1 Malang untuk dilakukan pengukuran parameter BOD dan COD.

2. Analisis pengukuran parameter BOD menggunakan metode analisis APHA.5210 B, untuk parameter COD menggunakan metode analisis Q1/LKS/19 ( Spektrofotometri )

\section{HASIL DAN PEMBAHASAN}

Hasil analisis laboratorium kandungan BOD dan COD dari inlet dan outlet masingmasing reactor dapat ditunjukkan pada Tabel 1 dan Tabel 2 sebagai berikut :

Tabel.1. Kandungan BOD pada masing-masing reaktor

\begin{tabular}{|c|c|c|c|c|}
\hline No & Tanggal & $\begin{array}{c}\text { Inlet } \\
(\mathrm{mg} / \mathrm{l})\end{array}$ & $\begin{array}{c}\text { Outlet Reaktor } \\
\text { Melati air } \\
(\mathrm{mg} / \mathrm{l})\end{array}$ & $\begin{array}{c}\text { Outlet Reaktor } \\
\text { Bambu air } \\
(\mathrm{mg} / \mathrm{l})\end{array}$ \\
\hline 1 & $9-4-2012$ & 39,05 & 4,2 & 7,85 \\
2 & $11-4-2012$ & & & 4,2 \\
3 & $11-4-2012$ & 46,15 & 2,6 & 8,8 \\
4 & $13-4-2012$ & & 4,2 & \\
5 & $13-4-2012$ & 71 & & \\
6 & $15-4-2012$ & & & \\
\hline
\end{tabular}

Tabel. 2. Kandungan COD pada masing-masing reaktor

\begin{tabular}{|l|c|c|c|c|}
\hline No & Tanggal & $\begin{array}{c}\text { Inlet } \\
(\mathrm{mg} / \mathrm{l})\end{array}$ & $\begin{array}{c}\text { Outlet Reaktor } \\
\text { Melati air (mg/l) }\end{array}$ & $\begin{array}{c}\text { Outlet Reaktor } \\
\text { Bambu air (mg/l) }\end{array}$ \\
\hline 1 & $9-4-2012$ & 79,73 & 10,44 & 22,6 \\
2 & $11-4-2012$ & & & \\
3 & $11-4-2012$ & 99,59 & 5,6 & 8,81 \\
4 & $13-4-2012$ & & & 14,62 \\
5 & $13-4-2012$ & 161,4 & 6,83 & \\
6 & $15-4-2012$ & & & \\
\hline
\end{tabular}

Dari hasil uji laboratorium berdasarkan tabel 1 dan tabel 2 diperoleh data kadar BOC dan COD air limbah Puskesmas Janti yang diambil dari inlet IPAL nya, untuk kadar BOD yaitu kisaran $39 \mathrm{mg} / \mathrm{l}$ $71 \mathrm{mg} / \mathrm{l}$ dan untuk kadar COD yaitu kisaran 79,73 - 161,4 mg/l, dari data tersebut menunjukkan bahwa karakteristiknya rendah. Saat pengambilan sampling air limbah hasilnya menunjukkan karakteristik rendah hal ini dimungkinkan limbah yang dihasilkan saat itu berasal dari kamar mandi dan wastafel poli-poli yang tidak fluktuatif. Sedangkan data hasil outletnya kadar BOD dan COD semakin hari hasilnya naik, hal ini dimungkinkan kondisi tanaman air yang digunakan pada saat itu memiliki masa tumbuh yang optimum serta media kerikil dengan diameter kecil ( $1 \mathrm{~cm}$ ) memiliki luas permukaan yang lebih besar sehingga keberadaan mokroorganismenya lebih banyak yang dapat berpengaruh lebih besar dalam pengolahan air limbah. 
1. Kandungan BOD Inlet dan Outlet Reaktor Melati Air dan Bambu Air.

Berdasarkan tabel 1. dapat digambarkan grafik penurunan kandungan BOD pada outlet reaktor Melati air dan Bambu air seperti pada gambar 2 berikut :

\section{KADAR BOD}

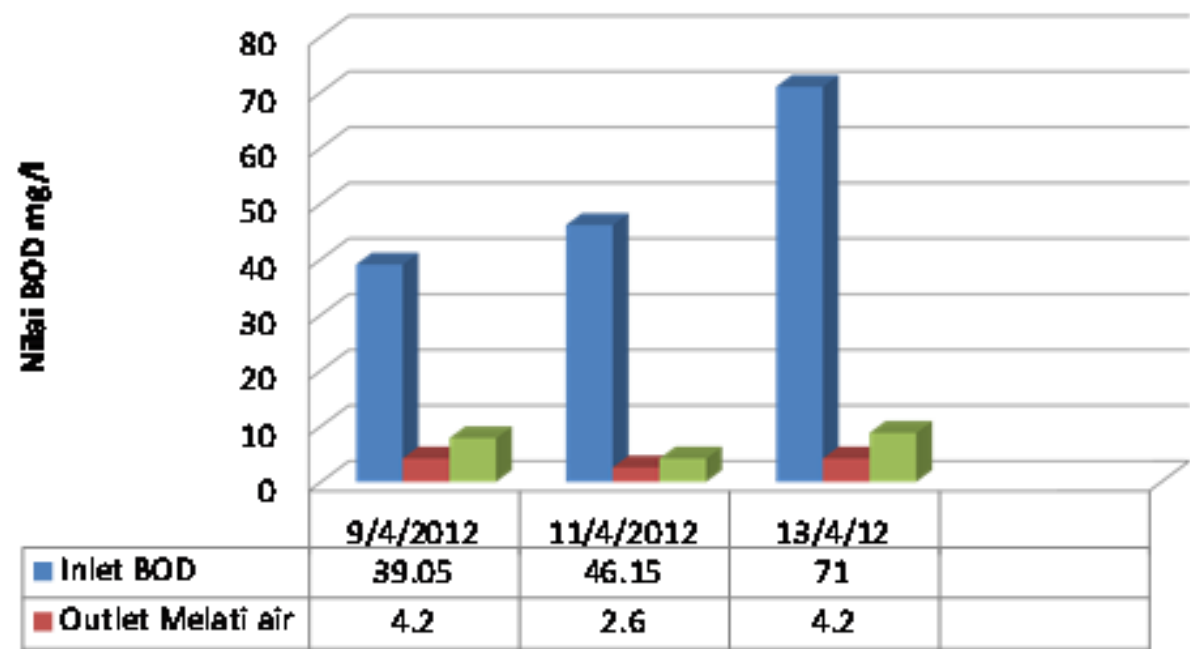

Gambar 2.Grafik Penurunan Kandungan BOD pada Reaktor MA dan BA

Grafik penurunan kandungan BOD pada gambar 4.4 menunjukkan penurunan yang signifikan terhadap kandungan BOD inlet dan outlet reaktor Melati air dan Bambu air yaitu kisaran 39,05 - $71 \mathrm{mg} / \mathrm{l}$ menjadi kisaran 2,6 - 4,2 mg/l untuk melati air dan kisaran 4,2 - 8,8 mg/l untuk bambu air. Penurunan ini dikarenakan proses filtrasi dan pengendapan yang terjadi oleh kerikil sebagai media tanam ditambah proses metabolisme dan penyerapan oleh tumbuhan air dalam hal ini Melati air dan Bambu air. Penurunan kandungan $\mathrm{BOD}$ pada outlet reaktor Melati air lebih tinggi dibandingkan penurunan BOD pada outlet reaktor Bambu air.

Penurunan kandungan BOD ini menunjukkan adanya pengaruh jenis tanaman terhadap penurunan kandungan BOD dalam penelitian ini, salah satunya dipengaruhi fungsi perakaran dalam menyerap dan mengurai polutan dan penurunan kandungan BOD. Sistem perakaran Melati air adalah kuat, panjang dan menjalar sehingga sangat efektif dalam memperluas area tempat mikroorganisme melekat.

2. Kandungan COD Inlet dan Outlet Reaktor Melati air dan Bambu air.

Berdasarkan tabel 2. dapat digambarkan grafik penurunan kandungan COD pada outlet reaktor Melati air dan Bambu air seperti pada gambar 3 berikut : 


\section{KADAR COD}

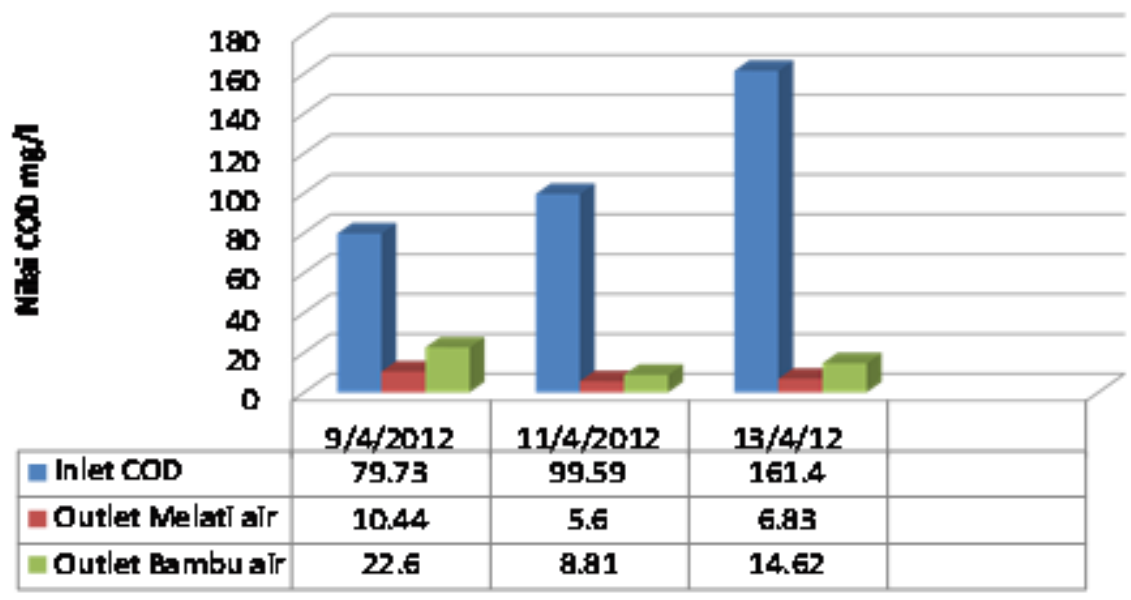

Gambar 3. Grafik Penurunan Kandungan COD pada Reaktor MA dan BA

Grafik penurunan

kandungan COD pada gambar 4.5

menunjukkan penurunan yang

signifikan terhadap kandungan COD

inlet dan outlet reaktor Melati air dan

Bambu air yaitu kisaran 79,73 -

$161,4 \mathrm{mg} / \mathrm{l}$ menjadi kisaran 5,6 -

$10,44 \mathrm{mg} / \mathrm{l}$ untuk melati air dan kisaran $8,81 \quad-22,6 \quad \mathrm{mg} / \mathrm{l}$ untuk bambu air. Penurunan ini dikarenakan proses filtrasi dan pengendapan yang terjadi oleh kerikil sebagai media tanam ditambah proses metabolisme dan penyerapan oleh tumbuhan air dalam hal ini Melati air dan Bambu air. Proses penurunan kandungan COD dalam sistem Wetland akan semakin baik bila digunakan media dengan ukuran partikel yang lebih kecil ( Schuls, 2000 dalam Fitria, 2002 ). Penurunan kandungan COD pada outlet reaktor Melati air lebih tinggi dibandingkan penurunan COD pada outlet reaktor Bambu air. Hal ini menunjukkan adanya pengaruh jenis tanaman terhadap penurunan kandungan COD dalam penelitian ini, salah satunya dipengaruhi fungsi perakaran dalam menyerap dan mengurai polutan dan penurunan kandungan COD. Sistem perakaran Melati air adalah kuat, panjang dan menjalar sehingga sangat efektif dalam memperluas area tempat mikroorganisme melekat.

3. Efisiensi Reaktor Melati Air dan Bambu Air

Perhitungan efisiensi penurunan kandungan BOD pada reaktor Melati air dan Bambu air dapat dilihat pada tabel 3 di bawah ini :

Tabel 3 Efisiensi Penurunan Kandungan BOD pada Reaktor Melati air dan Bambu air

\begin{tabular}{|r|c|c|c|c|c|}
\hline Tanggal & $\begin{array}{c}\text { Inlet } \\
(\mathrm{mg} / \mathrm{l})\end{array}$ & $\begin{array}{c}\text { Outlet Reaktor } \\
\text { Melati air } \\
(\mathrm{mg} / \mathrm{l})\end{array}$ & $\begin{array}{c}\text { Efisiensi } \\
\text { Melati air } \\
(\%)\end{array}$ & $\begin{array}{c}\text { Outlet Reaktor } \\
\text { Bambu air } \\
(\mathrm{mg} / \mathrm{l})\end{array}$ & $\begin{array}{c}\text { Efisiensi } \\
\text { Bambu air } \\
(\%)\end{array}$ \\
\hline $9-4-2012$ & 39,05 & 4,2 & 89,24 & 7,85 & 79,89 \\
$11-4-2012$ & 46,15 & 2,6 & 94,37 & 4,2 & 90,89 \\
$13-4-2012$ & 71 & 4,2 & 94,08 & 8,8 & 87,60 \\
\hline \multicolumn{2}{|r|}{ Efisiensi Rata-rata } & & 92,56 & & 86,13 \\
\hline
\end{tabular}


Berdasarkan Tabel 3. dapat digambarkan efisiensi penurunan kandungan BOD pada reaktor Melati air dan reaktor Bambu air dengan grafik seperti pada Gambar 4 di bawah ini :

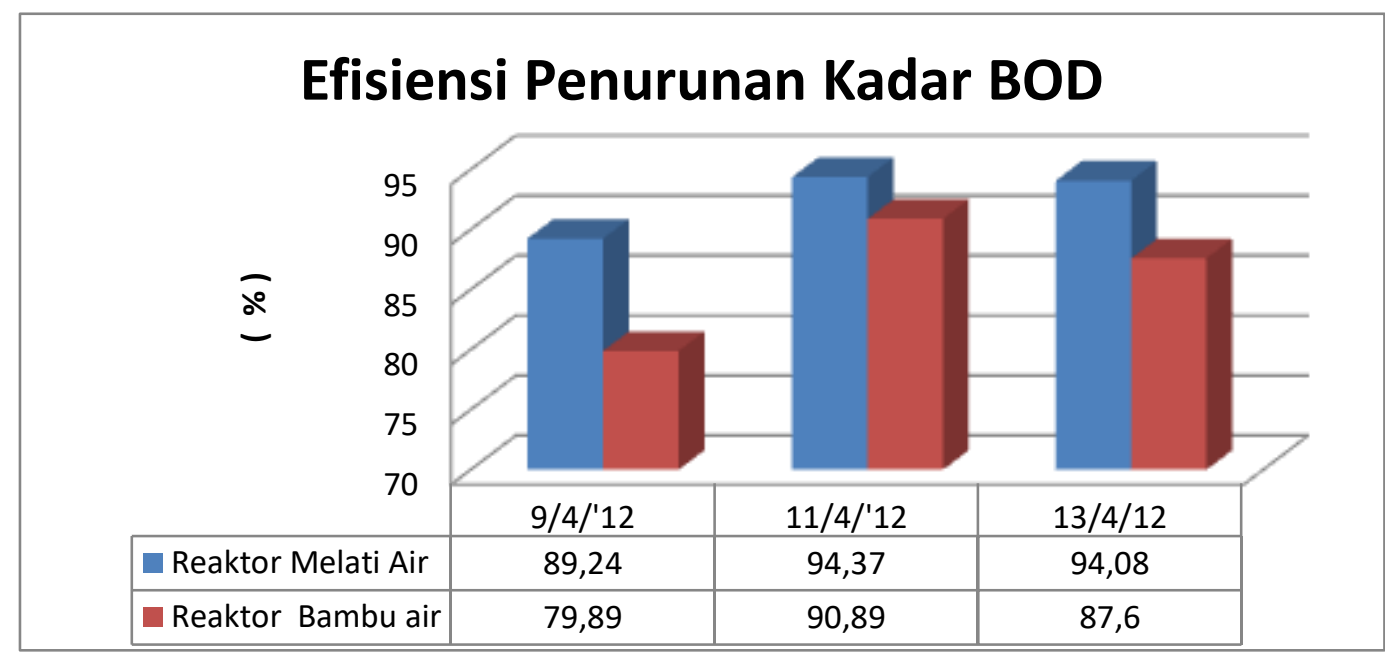

Gambar 4. Grafik Efisiensi Penurunan Kadar BOD

Berdasarkan Tabel 3 dan Gambar 4. diatas terlihat bahwa reaktor Melati air yang berisi media tanam dan tanaman melati air mempunyai efisiensi penurunan kandungan BOD kisaran $89,24 \%$ $94,37 \%$ atau rata-rata $92,56 \%$, sedangkan pada reaktor Bambu air yang berisi media tanam dan tanaman bambu air mempunyai efisiensi penurunan kandungan BOD kisaran $79,89 \%-90,89 \%$ atau ratarata $86,13 \%$. Hal ini menunjukkan adanya pengaruh tanaman dalam menguraikan polutan sehingga menurunkan kandungan BOD pada outlet reaktor

Perhitungan efisiensi penurunan kandungan COD pada reaktor Melati air dan Bambu air dapat dilihat pada tabel 4 di bawah ini :

\begin{tabular}{|r|c|c|c|c|c|}
\hline Tanggal & $\begin{array}{c}\text { Inlet } \\
(\mathrm{mg} / \mathrm{l})\end{array}$ & $\begin{array}{c}\text { Outlet } \\
\text { Reaktor } \\
\text { Melati air } \\
(\mathrm{mg} / \mathrm{l})\end{array}$ & $\begin{array}{c}\text { Efisiensi } \\
\text { Melati air } \\
(\%)\end{array}$ & $\begin{array}{c}\text { Outlet } \\
\text { Reaktor } \\
\text { Bambu air } \\
(\mathrm{mg} / \mathrm{l})\end{array}$ & $\begin{array}{c}\text { Efisiensi } \\
\text { Bambu air } \\
(\%)\end{array}$ \\
\hline $9-4-2012$ & 79,73 & 10,44 & 86,90 & 22,6 & 71,65 \\
$11-4-2012$ & 99,59 & 5,6 & 94,38 & 8,81 & 91,15 \\
$13-4-2012$ & 161,4 & 6,83 & 95,77 & 14,62 & 90,94 \\
\hline \multicolumn{2}{|l|}{ Efisiensi Rata-rata } & & 92,35 & & 84,58 \\
\hline
\end{tabular}


Berdasarkan Tabel 4 dapat digambarkan efisiensi penurunan kandungan COD reaktor Melati air dan reaktor Bambu air dengan grafik seperti pada gambar 5 dibawah ini :

\section{Efisiensi Penurunan Kadar COD}

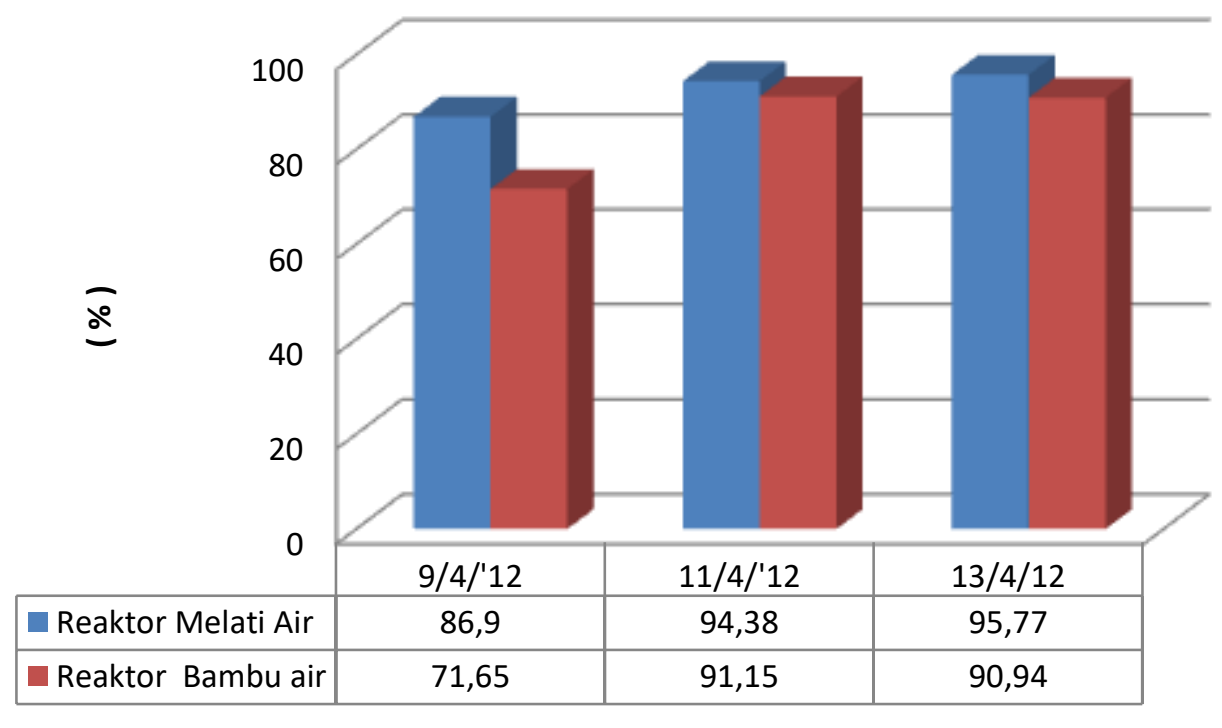

Gambar 5. Grafik Efisiensi Penurunan Kadar COD

Berdasarkan Tabel.4.4 dan Gambar 5 diatas terlihat bahwa Reaktor Melati air yang berisi media tanam dan tanaman melati air mempunyai efisiensi penurunan kandungan COD kisaran $86,90 \%-94,77 \%$ atau rata-rata 92,35 $\%$, sedangkan pada reactor Bambu air yang berisi media tanam dan tanaman bambu air mempunyai efisiensi penurunan kandungan $\mathrm{COD}$ kisaran $71,65 \%-90,94 \%$ atau rata-rata 84,58 $\%$. Hal ini menunjukkan adanya pengaruh tanaman dalam menguraikan polutan sehingga menurunkan kandungan COD pada outlet reaktor.

Perhitungan Perbedaan \% Efisiensi Penurunan Kadar BOD dan COD oleh Melati air dan Bambu air

Tingkat persen efisiensi dalam penurunan kadar BOD dari ke dua tanaman air yaitu melati air dan bambu air, ke duanya menunjukkan perbedaan yang signifikan. Melati air efisiensi penurunan kandungan BOD air limbah puskesmas rata-rata $92,56 \%$, sedangkan bambu air efisiensi penurunannya rata-rata sebesar 86,13 $\%$. Dari rata-rata efisiensi penurunan kandungan BOD air limbah puskesmas, menunjukkan bahwa tanaman melati air lebih efektif dari bambu air.

Tingkat persen efisiensi dalam penurunan kadar COD dari ke dua tanaman semi aquatic yaitu melati air dan bambu air, ke duanya juga menunjukkan perbedaan yang signifikan. Melati air efisiensi penurunan kandungan COD air limbah puskesmas rata-rata $92,35 \%$, sedangkan bambu air efisiensi penurunannya rata-rata sebesar $84,58 \%$. Dari rata-rata efisiensi penurunan kandungan $C O D$ air limbah puskesmas, juga menunjukkan bahwa tanaman melati air lebih efektif dari bambu air.

Proses pengolahan air
limbah pada sistem wetland
berlangsung melalui proses fisika, kimia
dan biologi yang disebabkan oleh
adanya interaksi mikroorganisme,
tanaman dan subtract, Mukhlis, ( 2003
).Sistem Wetland memanfaatkan sinar
matahari dan tanaman yang berfungsi
memfilter bahan pencemar dengan
bantuan mikroorganisme yang tumbuh
di perakaran tanpa menambahkan
bahan-bahan kimia dan prosesnya
berjalan alami.


Prinsip dasar sistem wetland untuk pengolahan air limbah adalah pada proses respirasi tumbuhan air. Tumbuhan air ini mampu menghisap oksigen dari udara melalui daun, batang, akar dan rhizomanya yang kemudian dilepaskan kembali pada daerah sekitar perakaran ( rhizosphere ). Hal ini dimungkinkan karena jenis tumbuhan air ini mempunyai ruang antar sel atau lubang saluran udara sebagai alat transportasi oksigen dari atmosfer ke bagian perakaran, dan proses yang lain adalah proses pengendapan dan penangkapan material partikulat di ruang hampa pada media tanam dan pertumbuhan mikroba pada permukaan media yang turut membantu menguraikan bahan organik.

Menurut Novonty dan Olen ( 1984 ), proses-proses yang terjadi di dalam sistem wetland secara lengkap meliputi proses fisika, fisika-kimia dan biokimia. Proses fisika terdiri dari proses sedimentasi dan filtrasi. Proses fisika-kimia terdiri dari proses adsorbs bahan pencemar oleh tanaman air, sedimen dan subtract organik. Sedangkan proses biokimia terdiri dari proses penguraian zat pencemar oloeh bakteri yang menempel pada permukaan subtract/media, perakaran tanaman, serta penyerapan nutrien dan zat-zat pencemar lainnya oleh tanaman.

\section{KESIMPULAN}

Dari hasil penelitian yang telah dilakukan dengan variasi jenis tanaman dan waktu tinggal selama 2 (dua) hari dapat disimpulkan sebagai berikut :

1. Hasil penelitian yang telah dilakukan menunjukkan bahwa karakteristik air limbah UPT Puskesmas Janti Kota Malang yaitu BOD kisaran $39-71$ $\mathrm{mg} / \mathrm{l}$ dan COD kisaran 79,73 - 161 $\mathrm{mg} / \mathrm{l}$, jadi karakteristiknya rendah.

2. Tanaman air yaitu melati air dan bambu air yang digunakan pada Contructed Wetland menunjukkan perbedaan dalam menurunkan kandungan BOD dan COD pada air limbah UPT Puskesmas Janti Kota Malang. Melati air lebih efektif dibanding bambu air dalam menurunkan kandungan $\mathrm{BOD}$ dan COD pada air limbah UPT Puskesmas Janti Kota Malang.

3. Tanaman air yaitu melati air dan bambu air yang digunakan pada Contructed Wetland sangat efisien dalam menurunkan kandungan BOD dan COD pada air limbah UPT Puskesmas Janti Kota Malang. Melati air efisiensi penurunan kandungan BOD air limbah puskesmas rata-rata $92 \%$, sedangkan bambu air efisiensi penurunannya rata-rata sebesar 86 $\%$.

Melati air efisiensi penurunan kandungan COD air limbah puskesmas rata-rata $92 \%$, sedangkan bambu air efisiensi penurunannya rata-rata sebesar 84 $\%$.

\section{DAFTAR PUSTAKA}

Anonymous, Aplikasi Wetland, Dhupalaka.files.wordpress.com.html diunduh tanggal 5-122011 jam 21.00 wib

Anonymous, Bambu Air ( Equisetum hyemale )

http://infonyasunflo.blogspot.com/2009/10/mengenal-bambu-air.html diunduh tanggal 18 1-2012 jam 20.40 wib

Anonymous, Contructed Wetlands.

http://www.twcno-preneur-net/information-desk/scientec Magazine / 2006/Contructed wetlands.pdf (Diakses 29 Januari $2012 ; 20.30$ )

Anonymous, Melati air ( Echinodorus palaefolius http://infonyasunflo.blogspot.com/2009/10/mengenal-melati-air.html diunduh tanggal 18 1-2012 jam 20.30 wib

Anonymous, Potensi dan Pengaruh Tanaman pada Pengolahan Air limbah Domestik dengan System Contructed Wetland, upn jatim.ac.id diunduh tanggal 5-12-2011 jam 20.30 wib 
Anonymous, Performance Contructed Wetland ( Penampilan TTA dalam Sistem Pengolahan Air limbah Rumah Sakit ). Images.soemarno. contens.com diunduh tanggal 512-2011 jam 21.20 wib.

Dhokkikah, Y, 2006. Pengolahan air bekas domestic Dengan Sistem Contructed Wetland Aliran Sub Surface untuk Menurunkan COD, TS dan Deterjen Surabaya : Institut Teknologi Sepuluh Nopember.

Fitriani, L. 2002. Sutdi Literatur Pemanfaatan Tumbuhan Air Untuk Pengolahan Limbah Cair Domestik. Surabaya : Institut Teknologi Sepuluh Nopember.

Hammer DA (ed).1998. Contructed Wetlands for Wastewater Treatment. Munipical, Industrial and Agricultural. Lewish Publieher, Chelsea, MI

Kurniawan, Hatta, 2005. Uji Kemampuan Tumbuhan Heliconia Rostrata dan Cyperus Papyrus dalam Menurunkan COD dan TSS pada Air Limbah KM/WV, Kantin ITS dan Laborat Lingkungan dengan Sistem Rawa Buatan, Surabaya, Institut Teknologi Sepuluh Nopember.

Khiatuddin,M,2003, Melestarikan Sumber daya Air dengan Teknologi Rawa Buatan. Gajah Mada University, Jogjakarta

Keputusan Gubernur Daerah Tingkat I Jawa Timur Nomor : 61 tahun 1999 tertanggal 19 juli 1999 tentang Baku Mutu Limbah Cair bagi Kegiatan Rumah Sakit di Propinsi daerah Tingkat I jawa Timur.

Mukhlis, 2003. Studi Kemampuan Tumbuhan Air Red dan Cattail dam Sistem Contructed Wetlands untuk Menurunkan COD dan TSS Air Limbah. Surabaya: Institut Teknologi Sepuluh Nopember.

Metcalf and Eddy, 2003 "Wastewater Engineering : Treatment, Disposal, and Reuse " Mc Graw Hill Inc.New York

Meutia,A, 2001. Lahan Basah Buatan di Indonesia, Wetlands In ternational - Indonesia Programme, Bogor

Novonty, V and Olem, 1984, Water Quality: Prevention, Identification and management of Diffuse Polutan. Van Nostrand Reinhold, New York

PP Nomer 20 Tahun 1990 tentang Pengendalian Pencemaran Air

Prasetyaningtyas, Dyan, 2003. Evaluasi Kerja Sistem Subsurface Flow Contructed Wetlands pada IPAL Domestik Tlogo Mas Malang. Surabaya : Institut Teknologi Sepuluh Nopember.

Riswahyudi, 2010. Penurunan Kandungan Nitrat Oleh Tanaman Eceng Gondok, Melati Air Dalam Sistem Subsurface Contructed Wetland. Surabaya: Universitas PGRI Adi Buana

Said, 2006. "Kesehatan Masyarakat dan Teknologi Peningkatan Kualitas Air", Direktorat Teknologi Lingkungan, Jakarta.

Sutrisno dan Suciastuti, 1987." Teknologi Penyedia Air Bersih “ Rineka Cipta , Jakarta. 